\title{
ARBITRATION AS AN AID IN THE ENFORCEMENT OF THE ANTITRUST LAWS
}

\author{
JAMES V. HAYES*
}

This article is concerned only with the use of arbitration as an instrument in the enforcement of decrees entered under the antitrust laws. It will consider (a) whether a court possesses the power to order an arbitral system to give effect to the provisions of its decree, and (b) the advisability of so doing.

\section{Difriculties in the Enforcement of Antitrust Decrees}

Probably the chief deficiency in the administration of the antitrust laws is the difficulty of enforcing decrees, both consent and litigated decrees. There are two methods by which enforcement effect can be given to an antitrust decree. The first and direct procedure is the institution of contempt proceedings. Such proceedings are by their very nature cumbersome, lengthy, and expensive. They must be litigated either before the court or before a master appointed by the court. To sustain its burden the Government may have to prove a course of conduct involving numerous transactions in various parts of the country. ${ }^{1}$ Being penal in character strict rules

C.P.A., state of New York, 1922; LL.B. 1924, Fordham University Law School. Member of the law firm of Donovan, Leisure, Newton, Lumbard and Irvine, New York City. Member of the Ncw York and District of Columbia bars. Co-author [with Francis P. LeBuffe, S. J.] of Jurisprudence (3d cd. 1938) and Tre American Phmosophy of Law (4th ed. 1947). Contributor to Fordham Latw Reviciv, Cornell Law Quarterly, Arbitration Journal, and other reviews.

${ }^{I}$ Investigntion of Concentration of Economic Power, Motion Picture Industroy (TNEC Monograph 43, 194I). For the same conclusion, see Comment, Legislation by Consent in the Motion Picture Industry, 50 YALE L. J. 854, 875 (I94I).

"Moreover, a legal victory is one thing; its practical realization in the reform of the industry is something else. The court lays down the law; but it possesses no facilities for secing that the terms of the decree are carried out. It has plenary power to punish for contempt but it lacks means for discovering that its orders are not obeyed. If the victory in court is to make a difference in the conduct of the industry, the decree must be policed. Thus the problem is thrown back upon the enforcement agency which, save for the opportunity to invoke contempt, is exactly where it was before the trial began. Actually the (anti-trust) Division, as at present financed and staffed, is quite unable to undertake a task of such magnitude in the oversight of industrial activity. As matters currently go, the decree of the court-whether for or against the Government-is looked upon as ending the case. The defendants, as law-abiding citizens, are presumed to amend their practices and give no further causc for complaint. The Division moves its personnel to another troubled spot along the industrial front.

"The task of policing falls to the industry itself. Without a court to guide and Justice to supervise, the wrongdoer is left to mend his own way." Contempt has been but infrequently used as an enforcement weapon. ANTI-TRUst IN ACrion 77 (TNEC Monograph 16, 194I).

Although it has never happened in an antitrust case, under Fed. Rules Civ. Proc. Rule 7x, 28 U. S. C. A. (1950) a person aggrieved by a defendant's violation of a decree may sometimes bring contempt proceeding himself even though he was not a party to the action. In Woods v. O'Brien, 78 F. Supp. 22I (D. Mass. I948) a tenant was allowed to hold his landlord in civil contempt for violating a permanent injunction obtained by the Housing Expediter. This case is distinguishable from the usual antitrust situation because the injunction named the complainant as the one not to be evitted. In the antitrust field the defendant's competitors who are supposed to be benefited are not customarily 
of evidence apply. An appeal lies from the court's decision and final determination may not be reached for years. In the meantime the questioned practices may continue. At any rate their continuance is under the control of the defendants who may feel that the abandonment of them might be construed as an admission. Further, the Antitrust Division does not have adequate personnel to police its decrees. Its manpower is for the most part engaged in the investigation of complaints and in the maintenance' of numerous criminal and equity actions, a substantial number of which fall into the category of the Big Case. ${ }^{2}$ In the light of these considerations it is not surprising that the record of the use of contempt proceedings to enforce antitrust decrees is not impressive. ${ }^{3}$

The second and indirect method of giving enforcement effect to antitrust decrees is by their use as evidence in treble damage actions instituted by persons affected by the practices banned by the decree. ${ }^{4}$ Consent decrees entered before the taking of testimony, however, may not be received as evidence in a treble damage suit. Such a suit has little enforcement effect and the plaintiff must prove his case as fully as if the Government action had never been brought. It is only treble damage suits brought against defendants who are parties to a litigated Government decree that have any substantial enforcement effect and it is clear that the prior Government decree will not be received in evidence in many such cases. ${ }^{5}$ Further even in those cases years are consumed in pre-trial procedures and discovery before the case is ready for trial, and from the judgment entered an appeal lies. At best private antitrust suits are expensive and time consuming for all parties, and the results are most uncertain. ${ }^{6}$

\section{named in the decree.}

If the decree specifically retains jurisdiction to allow an aggrieved third person to apply to the court for relief, such person may sue in his own capacity. United States v. Paramount Pictures, Inc., 75 F. Supp. ro02 (S. D. N. Y. 1948). Where the decree fails to do so, the only resort of such a person is to intervene by permission under 28 U. S. C. A. Rule 24 (b). United States v. Paramount Pictures, Inc., stipra; cf. United States v. Bendix Home Appliances, ro F.R.D. 73 (S. D. N. Y. r949). Permission to intervene after the issuance of the decree is unusual though obtainable to protect otherwise unprotectable rights. Wolpe v. Poretsky, I44 F.2d 505, cert. denied, 323 U. S. 777 (1944).

${ }^{2}$ Suggestions for improving the handling of trials of antitrust cases to save time and yet obtain definitive decisions are advanced in Procedure in Anti-Trust and Other Protracted Cases, Judicial Conference of the United States, I951, and McAllister, The Big Case: Procedural Problems in Antitrust Litigation, 64 Harv. L. REv. 27 (I950).

${ }^{3}$ See note I supra.

- 38 Stat. 73 I (I9I4), I5 U. S. C. A. \$I6 (I95I) (Clayton Act, Section 5) provides in part:

"A final judgment or decree rendered in any criminal prosecution or in any suit or proceeding in equity brought by or on behalf of the United States under the antitrust laws to the effect that a defendant has violated said laws shall be prima facie evidence against such defendant in any suit or proceeding brought by any other party against such defendant under said laws as to all matters respecting which said judgment or decree would be an estoppel as between the parties thereto: Provided, This section shall not apply to consent judgments or decrees entered before any testimony has been taken."

${ }^{5}$ See Emich Motors Corp. v. General Motors Corp. 340 U. S. $55^{8}$ (195I) for an examination of the problems in determining the admissibility and the scope and effect of litigated decrees.

'Donovan and Irvine, Proof of Damages under the Antitrust Law, 88 U. of PA. L. REv. 5 II, 524 (1940): "In providing for treble damages under the anti-trust laws, Congress had clearly in mind the extreme difficulty of maintaining a private suit under those laws. The experience over the past 7o rears suggests that Congress underestimated the enormity of the task assumed by a plaintiff seeking three- 
Not the least of the difficulties in any of these procedures is that the practices enjoined are not always described with nicety and clarity. Some decrees do little more than enjoin the defendants from violating the antitrust laws. Enforcement proceedings are thus little different from an original proceeding. Other existing decrees contain specific and clear or relatively clear directions as to the future conduct of the defendants bound thereby. The difference between these types of decree is important in any consideration of the use of arbitration as an aid in the enforcement of these laws. When a decree does no more than enjoin the defendants from violating the antitrust laws, arbitration as a means of enforcement has little to offer. The decree couched in specific language, however, supplies a norm over and above that contained in the law by which to judge whether the defendants have conformed their conduct to its provisions. To determine compliance it is not necessary to apply the basic principles of the antitrust laws. In such cases the well-informed layman sitting as an arbitrator can as readily and accurately judge the conformity of the defendants' conduct to the specific provisions of the decree as can a court possessed of no special experience or skill in the particular industry. It is only with respect to such decrees that arbitration can play a part.

The need for more effective enforcement procedures grows in large part out of the fact that the immediate intended beneficiaries of an antitrust decree are usually those competitors who have been adversely affected in their businesses by the illegal conduct of the defendants. It is they who are directly injured by any continuance of the proscribed conduct. If an antitrust decree is framed in broad general language it may well be that the only effective remedy available to such a competitor is complaint to the Antitrust Division in the hope that the Division will institute a contempt proceeding. Where, however, an antitrust decree prescribes specific future affirmative acts or proscribes specific future negative acts on the part of the defendants it would appear that some expeditious and effective weapon should be forged which could be wielded by the injured third person without resort to the Antitrust Division. So far as enforcement is concerned such a procedure would be vastly preferable to the maintenance of a contempt proceeding.

The experience with a system of arbitration in the motion picture industry, which is treated in some detail below, suggests that arbitration is, at least, one speedy, inexpensive and effective method to secure enforcement of an antitrust decree. It is not within the scope of this article to describe in detail any particular system of arbitration, e.g., to discuss such questions as the character of the arbitrators and whether they should be lawyers or economists or businessmen experienced in the particular industry, the number of arbitrators, the administration of the arbitral

fold damages. Even a cursory examination of the cases will show that most combinations have been cleverly concealed behind an exterior of plausible legality. The initial problem merely of proving their existence is one which few persons can afford to undertake. If the existence of the combination is shown, the complicated factual and economic problems presented are equally disturbing to a private litigant. In establishing the nature of the combination and the cause of his injury, the Court holds the plaintiff to a high degree of definite proof. It is therefore not surprising that in spite of the liberal trend of the decisions dealing with proof of damage the number of recoveries has been small." 
system, the existence of an appeal board similar to that which existed during the life of arbitration in the motion picture industry, the method of financing the system, and other related matters. It may well be that no one system will fit all industries and that, if a court decides to prescribe the use of arbitration, the arbitral system will have to be custom-tailored to the particular industry. This is an advantage rather than a drawback since the adaptability of arbitration to varying conditions and circumstances is one of its chief attractions.

Consideration will be limited, therefore, to the basic questions as to whether a court entering an antitrust decree has the power to compel the defendants to arbitrate at the demand of third persons questions which may arise as to violations by defendants of the provisions of the decree and, if so, whether it is wise to do so.

Arbitration is not proposed as a panacea. It, too, has its shortcomings. Obviously not every question of compliance is susceptible of determination by arbitration. Obviously, too, arbitration cannot eliminate the contempt remedy in a proper case. What is proposed is the use of the arbitral method to enable third persons affected by the failure of defendants to comply with the provisions of a decree to obtain a speedy and effectual remedy, thus lessening, if not eliminating, the need for expensive and lengthy treble damage actions.

\section{The Power of the Court to Compel Arbitration}

There is no doubt that a court can approve an agreement by the Government and defendants to establish a system for arbitrating future disputes arising under the decree. ${ }^{7}$ Such a provision, however, could not limit private parties to the use of the arbitral system. The arbitration remedy must be optional with the private party. Else a deprivation of the statutory right to treble damages in a particular case would result. ${ }^{8}$ This basic rule applies whether the decree providing for arbitration is a consent or litigated decree.

Whether a court has power to decree that defendants in a Government antitrust

\footnotetext{
7 The consent decree drawn up by the parties themselves, though not usually extensively modified by the court, is not a mere contract of the parties but a formal judicial act. United States v. Swift \& Co., 286 U. S. I06, II5 (1932). If the pleadings alleged appropriate violations of the law, the court gets sufficient jurisdiction to approve a consent decree and bind the parties even though no proof has been taken. Swift \& Co. v. United States, 276 U. S. 3 II, 329 (r928). It has been held that setting up in consent decrees "broad codes" covering matters not closely connected with antitrust violations may be error but it is not jurisdictional and therefore not reviewable. Swift \& Co. v. United States, supra. But sce United States v. New York Coffee and Sugar Exchange Inc., 263 U. S. 61r, 621 (I924):

"The Government in effect asks this Court to enforce rules and regulations for the conduct of the Sugar Exchange which shall prevent the future abuse of its lawful functions. This is legislative and beyond our power." There the Government failed to prove that the defendant had violated the antitrust laws though it did show that the defendant's practices were susceptible of unfair use by others. While the case did not involve a consent decree it is interesting to speculate if this earlier Supreme Court would have found "broad codes" imposed by a consent decree to be beyond its jurisdiction.

${ }^{8}$ United States v. Paramount Pictures, Inc., 334 U. S. 131 , $\times 76$ (1948): "The use of the system would not, of course, be mandatory. It would be merely an auxiliary enforcement procedure, barring no one from the use of other remedies the law affords for violations either of the Sherman Act or of the-decree of the court."
} 
suit shall be compelled to arbitrate future disputes and to be bound by awards, including awards for money damages, has never been expressly decided. Prior to the decision of the Supreme Court in the Paramount case ${ }^{0}$ it appears to have been generally accepted that no such power existed and that to bring it into being legislative action would be necessary, the doubt as to power being based possibly on the ground that to grant arbitrators the broad powers necessary for their effective operation would be an abdication of judicial authority. ${ }^{10}$ This belief, though general, was not based on any decided cases for there were none. As appears below we get some light from the Supreme Court's decision in the Paramount case. Aside from that decision, however, it would seem on principle that when a court of equity has jurisdiction over the parties and the subject matter it can use any effective means that do not violate fundamental rights to secure compliance with its decree.

If a court which has found violations of the antitrust laws can direct a defendant to discontinue branches of its business or to divest itself of a large part of its assets or to avoid forever certain modes of conduct, ${ }^{11}$ then it seems clear enough that a court could direct a defendant to continue certain types of conduct or to refrain from other types of conduct upon the condition that it would arbitrate at the demand of third persons adversely affected thereby any question as to whether it had failed to obey the decree.

The only case which discusses the power of a court to set up an arbitral system through the medium of an antitrust decree is United States v. Paramount Pictures, Inc. ${ }^{12}$ The Paramount case was instituted in $193^{8}$ and a consent decree was entered in November I940.13 That decree provided for a system of arbitration of disputes arising out of alleged violations of the decree. ${ }^{14}$ The decree was final and it precluded the Government from seeking any additional relief, such as divestiture, for a period of three years. ${ }^{15}$ The Government reopened the case in 1944 before a statutory court. That court, in its opinion, spoke highly of the work of the arbitra-

- United States v. Paramount Pictures, Inc., 334 U. S. r3I (r948).

${ }^{10}$ Mid-West Theatres Co. v. Cooperative Theatres of Michigan, Inc., 43 F. Supp. 216 (E. D. Mich. I94I) suggests a legislatively constituted administrative agency; United States v. Paramount Pictures, Inc., 66 F. Supp. 323, 333 (S. D. N. Y. 1946). Donovan and McAllister, Consent Decrees in the Enforcement of Federal Antitrust Laws, 46 HARv. L. REv. 885, 915 (I933) proposes an arbitral enforccment system but indicates that enabling legislation would be required. Legislation by Consent in the Motion Picture Industry, 50 YALE L. J. 854, 870 (I94I): "It is questionable whether such arbitration could have been imposed upon losing defendants if the Government had won its suit. The Sherman Act gives the courts power to enjoin or otherwise prohibit illegal practices and it might be doubted if this could be extended to allow for organization and operation of arbitration machinery."

Probably the reason behind this position is the similarity between the proposed arbitration boards and the usual administrative agency which is always legislatively constituted.

11 "Divestiture or dissolution must take account of the present and future conditions in the particular industry as well as past violations. It serves several functions:

(I) It puts an end to the combination or conspiracy when that is itself the violation.

(2) It deprives the anti-trust defendants of the benefits of their conspiracy.

(3) It is designed to breal up or render impotent the monopoly power which violates the Act."

Schine Chain Theatres, Inc. v. United States, 334 U. S. I10, 128-129 (r948).

${ }^{12} 66$ F. Supp. 323 (S. D. N. Y. 1946), modified, 334 U. S. I31 (1948).

${ }^{13} 3 \mathrm{CCH}$ Trade Reg. SERv. $\rrbracket_{25,558 .}$.

${ }^{15}$ Id. \$XXI. 
tion system set up under the I940 consent decree and of the savings of time and money under arbitration as compared with court actions. As to the form of the decree to be entered pursuant to its decision the court said: ${ }^{\mathbf{1 6}}$

The decree shall also provide for arbitration of disputes as to bids, clearances, runs, and any other subjects appropriate for arbitration in respect to all parties who may consent to the creation of such tribunals for adjustment of such disputes. It shall also provide for an appeal board generally similar to the one created by the consent decree as to any parties consenting thereto. It shall make such disposition of the provisions of the existing consent decree signed November $30, x 940$, as may be necessary in view of the foregoing opinion.

The court was of the opinion, however, that it could not compel arbitration without the consent of the parties, saying: ${ }^{17}$

It would seem to follow that we cannot bind any parties to subject themselves to the arbitration system or the board of appeals set up in aid of it without their consent, even though we may regard it as desirable that such a system, in view of its demonstrated usefulness, should be continued in aid of the decree which we propose to direct.

The Supreme Court affirmed in part and reversed in part, the majority saying::18

We agree that the government did not consent to a permanent system of arbitration under the consent decree and that the District Court has no power to force or require parties to submit to arbitration in lieu of the remedies afforded by Congress for enforcing the anti-trust laws. But the District Court has the power to authorize the maintenance of such a system by those parties who consent and to provide the rules and procedure under which it is to operate. The use of the system would not, of course, be mandatory. It would be merely an auxiliary enforcement procedure, barring no one from the use of other remedies the law affords for violations either of the Sherman Act or of the decree of the court. Whether such a system of arbitration should be inaugurated is for the discretion of the District Court.

Thus the majority clearly held that the lower court could not bind third parties to use an arbitration system since that would deprive them of their other legal remedies. The majority also held that the lower court could not "require parties to submit to arbitration in lieu of the remedies afforded by Congress for enforcing the anti-trust laws."

By its language the majority may have meant that no remedy other than the established legal remedies, to wit, contempt or treble damage suits, may be used to enforce the terms of the decree, or it may have meant that an arbitral system could not be established without consent which would be a substitute for the established remedies as a method of enforcement. Since the words "in lieu of" mean "in place of" or "instead of" it would seem that it was the latter meaning which the court had in mind. If this be so it would seem clear that the majority did not deny that the lower court was possessed of the power to provide in its decree for the

\footnotetext{
${ }^{10}$ United States v. Paramount Pictures, Inc., 66 F. Supp. 323,359 (S. D. N. Y. 1946).

17 Id. at 333 .

${ }^{18}$ United States v. Paramount Pictures, Inc., 334 U. S. I3I, 176 (1948).
} 
establishment of an arbitral system, regardless of the consent of the parties, provided resort to other established legal remedies was fully preserved.

In his dissent Mr. Justice Frankfurter clearly states his opinion that the lower court could order arbitration without the consent of the defendants, saying: ${ }^{10}$

Accordingly, I would affirm the decree except as to one particular, that regarding an arbitration system for controversies that may arise under the decree. This raises a pure question of law and not a judgment based upon the facts and their significance, as are those features of the decree which the Court sets aside. The District Court indicated that "in view of its demonstrated usefulness" such an arbitration system was desirable to aid in the enforcement of the decree. The District Court, however, deemed itself powerless to continue an arbitration system without the consent of the parties. I do not find such want of power in the District Court to select this means of enforcing the decree most effectively, with the least friction and by the most fruitful methods. A decree as detailed and as complicated as is necessary to fit a situation like the one before us is bound, even under the best of circumstances, to raise controversies involving conflicting claims as to facts and their meaning. A court could certainly appoint a master to deal with questions arising under the decree. I do not appreciate why a proved system of arbitration, appropriate as experience has found it to be appropriate for adjudicating numberless questions that arise under such a decree, is not to be treated in effect as a standing master for purposes of this decree. See Ex parte Peterson, 253 U. S. 300. I would therefore leave it to the discretion of the District Court to determine whether such a system is not available as an instrument of auxiliary enforcement. With this exception I would affirm the decree of the District Court.

The statutory court, on remand, did not exercise the discretion which Mr. Justice Frankfurter said that it had. Again it suggested arbitration without ordering it, saying. ${ }^{20}$

The arbitration system and the Appeal Board which has been a part of it have been useful in the past and as we understand it have met with the general approval of the plaintiff and of those defendants who have agreed to it. In our opinion it has saved much litigation in the courts and it should be continued. Accordingly, the three major distributor-defendants and any others who are willing to file with the American Arbitration Association their consent to abide by the rules of arbitration and to perform the awards of arbitrators, should be authorized to set up an arbitration system with an accompanying Appeal Board, which will become effective as soon as it may be organized after the decree to be entered in this action shall be made, upon terms to be settled by the court upon notice to the parties to this action.

There is a ring of realism to Mr. Justice Frankfurter's dissent and, as mentioned above, the majority does not appear to have passed on the precise point. Whether an arbitral system be considered as a "standing master" as he suggests or as an exercise of the inherent power of a court of equity to fashion its judgments to the end sought, it would seem that a court has the power to direct defendants to arbitrate, at the request of a third party, questions involving alleged violations of the provisions of a decree, and that an arbitrator, acting under an arbitral system established by a court,

${ }^{20} \mathrm{Id}$. at $\mathrm{I8 \textrm {I }}$.

${ }^{20}$ United States v. Paramount Pictures, Inc. 85 F. Supp. 88 r, 899 (S. D. N. Y. 1949). 
would have the power to assess damages or to direct either affirmative or negative action as prescribed in the decree if he found that the defendants violated its provisions.

The constitutional right to a trial by jury would not be invaded by the establishment of such an arbitral system. That right does not exist in equity. ${ }^{21}$ Once an equity court takes jurisdiction of a matter, it retains its usual procedure even though subsequent acts, considered separately, would give rise to a trial by jury. ${ }^{22}$ An arbitration proceeding under a decree would, in effect, be equivalent to a proceeding in equity to enforce the terms of a decree and not a common law action. Requiring the defendants to pay money damages to a third party for violation of the decree or to take some specific action with respect to such third person is no more than rendering effective a decree already entered. ${ }^{23}$ Nor would the establishment of an arbitral system be an unwarranted delegation of judicial authority. The powers that would be given to the arbitrators would be no broader than the powers which a district court can give a master under Rule 53 of the Federal Rules of Civil Procedure. ${ }^{24}$ And it should, perhaps, be mentioned that the type of arbitration procedure suggested contemplates review of the arbitrator's actions by the court which entered the decree.

\section{III}

\section{Arbitration in the Motion Picture Industry}

In the abstract arbitration seems to offer a swift, cheap and fair way of allowing those most interested in the enforcement of a decree to police it and at the same time protect their own interests. Since, however, the theorist frequently brushes off aspects of an idea which would give pause to the man in the market place, we must be careful lest we produce an unwanted orphan. Fortunately, we have the results of more than three years' actual experience under an established system of arbitration in the motion picture industry which we can analyze and examine for unthought of "bugs."

The Motion Picture Tribunal, as it was called, was set up pursuant to the consent decree of November 20, 1940, entered into by the Government and five major corporations who together represented a very substantial part of the production,

${ }^{21} \mathrm{U}$ S. CONST. AMEND. VI. "In suits at common law where the value in controversy shall exceed twenty dollars, the right of trial by jury shall be preserved, and no fact tried by a jury, shall be otherwise re-examined in any Court of the United States, than according to the rules of the common law." Barton v. Barbour, 104 U. S. I26 (I88x).

${ }^{22}$ Barton v. Barbour, 104 U. S. 126 (I88I). The Supreme Court reaffirmed the doctrine of this case as late as 1950 in United States v. Louisiana, 339 U. S. 699.

${ }^{23}$ These arbitration procedures are closely analogous to proceedings in equity to punish for civil contempt for violations of the decree. Therc is nothing novel about requiring in such cases that the fine be paid to the injured party. Gompers v. Bucks Stove \& Range Co., 22I U. S. 4I8, 448 (I9II). In United States v. United Mine Workers of America, 330 U. S. 258, 304 (1947) the Supreme Court reaffirmed the Gompers case saying: "Where compensation is intended, a fine is imposed, payable to the complainant. Such fine must of course be based upon evidence of complainant's actual loss ...."

${ }^{24}$ FED. R. Crv. P. 53, 28 U. S. C. A. (1950). 
distribution, and exhibition of motion picture films. ${ }^{25}$ The decree outlined specific trade practices which were to be eliminated, changed the usual business methods concerning others, and prohibited still others unless practiced in a reasonable way. With respect to the system of arbitration established by the decree, the American Arbitration Association agreed to provide facilities in thirty-one film exchange areas throughout the country and also to supervise their operation. Any exhibitor who agreed to be bound by the award could complain against any distributor. Provision was made for any interested party to intervene in an arbitration. Likewise the decree included a provision allowing exhibitors and distributors by agreement to use the arbitration facilities to settle any questions arising between them on any matter. ${ }^{20}$

A final Appeal Board was set up and appointments to it were made by the district court which approved the decree. The rules of procedure were designed to avoid delay and expense without sacrificing substantial rights. Finally, the court retained jurisdiction to punish violations of an arbitrator's award.27 Since neither the American Arbitration Association nor exhibitor complainants were parties to the decree, only the Government could move to punish such violations. The Department of Justice set up a special unit to aid exhibitors in enforcing their rights and generally to oversee the operation of the arbitral system. ${ }^{28}$ Thereby the practical everyday working of the decree was closely policed.

Before looking at the accomplishments of the Motion Picture Tribunal from the viewpoint of bare statistics it is here pertinent to set forth the considered opinion of the statutory court on its success. One of its "conclusions of fact" in the reopened case after the three year trial period had elapsed reads: ${ }^{20}$

The arbitration system created by the Consent Decree of November 20, 1940, has demonstrated its usefulness in dealing with exhibitor's complaints of unreasonble clearance and if extended to cover differences which may occur under the system to be established by the Decree herein, will be effective and result in quick and expeditious decisions and a saving of time and money.

Speaking generally the court noted: ${ }^{30}$

... these Tribunals have dealt with trade disputes, particularly those as to clearances and run, with rare efficiency as both government counsel and counsel for other parties have conceded.

We strongly recommend that some such system be continued in order to avoid cumber-

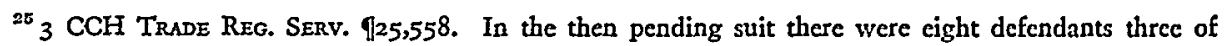
whom decided not to enter into the consent decree. The decree was made conditional on the successful prosecution of the three non-signers by June $\mathrm{I}$, I942. It also provided for a three year trial period after which any party could withdraw and the Government could renew the suit. Even though the condition with respect to the three non-consenting defendants was not complied with, the signing defendants nevertheless continued to live up to the terms of their agreement.

${ }^{20}{ }_{3} \mathrm{CCH}$ TrAde Reg. Serv. I25,558, Rules of Arbitration and Appeals, $\$ X X$; Haycs, Provisions of the Consent Decree, 5 Arb. J. 15, 24 (194r).

${ }_{27} 3$ CCH Trade Reg. Serv. q25,558, §XXIII.

${ }^{28}$ Department of Justice Release, Jan. 16, 194x.

${ }^{20}$ United States v. Paramount Pictures, Inc., 70 F. Supp. 53, 71 (S. D. N. Y. 1946).

${ }^{30}$ Id. at 76 . 
some and dilatory court litigation and to preserve the practical advantages of the Tribunals created by the Consent Decree.

These conclusions are amply supported by the cold figures. During the three year operation of the Tribunal, $4 \mathrm{1} 6$ complaints were filed, 283 awards were made, I22 appeals were taken, and III appellate decisions handed down. A total of I32 cases were settled before award. There is, of course, no method of determining the number of controversies that were ironed out without resort to the Tribunal that would not have been satisfactorily concluded had the arbitration facilities not been available. Of the cases terminated by award, exhibitors won I 77 and distributors Io6, of the appeals, 65 ended in favor of exhibitors and 46 in favor of the distributors. ${ }^{31}$

An interesting general comparison is afforded by considering that from I8go when private parties were first given the right to sue for treble damages under the antitrust laws until the time of the motion picture consent decree, approximately I75 cases of private suits are found as reported decisions. These embrace almost 90 different fields of commerce. The plaintiffs recovered in only I3 of these cases. Once again we have no way of determining the number of cases settled favorably to plaintiffs. $^{32}$

A specific indication of the effectiveness of the arbitral system established by the consent decree is apparent from the following facts. From about 1925 when the motion picture business became a major industry in this country until operations began under the consent decree in I940, there were approximately 184 complaints filed in court against industry members charging violation of the antitrust laws and seeking equitable relief or treble money damages or both. From I940 to I945, the approximate dates of the effective life of the arbitral system of the consent decree, there were about $\sigma_{3}$ such complaints filed. Since the lapse of the consent decree until the present, i.e., from 1946 through 195 I, there have been at least 303 antitrust complaints filed against the industry. Most of these, moreover, have sought treble damages, not simply injunctions. ${ }^{32^{2}}$

During the six months period, February I to July 3 I, I942, i.e., the twelfth to eighteenth month of the Tribunal's existence, the average cost including cost of stenographer for each arbitration totaled $\$ 58.23$ for an exhibitor complainant. This figure does not include the costs of appeal nor the complainant's attorney's fees. On the same basis the average cost to a distributor defendant was $\$ 29.64$. The disparity is explained by the fact that in many cases several distributors were joined and their costs were divided.

The five consenting distributors by the terms of the consent decree bore the cost

${ }^{31}$ Record on Appeal to the Supreme Court of the United States, United States v. Paramount Pictures, Inc. (p. 1859). At the time of this testimony one case had been reopened, hence the discrepancy between the total complaints on the one hand and the total awards and settlements on the other.

${ }^{32}$ Donovan and Irvine, Proof of Damages under the Antitrust Law, 88 U. of PA. L. REv. 5II, 524 (1940).

${ }_{32 a}$ Communication from Motion Picture Association, Jan. II, 1952. 
of establishing and operating the whole arbitration system, exclusive of arbitrators' fees, the cost for the first year being $\$ 300,0000^{33}$ This figure is high because the decree required that separate offices be staffed and maintaind in thirty-one different cities across the country. If the established nationwide facilities of such an organization as the American Arbitration Association were used, the costs would then be cut down to the level of the usual commercial arbitration cases. ${ }^{34}$

No final appraisal can be made of the worth and effectiveness of the Motion Picture Tribunal unless the opinions of those intended to be helped and protected by it are consulted. The Tribunal was designed to afford to the exhibitors with whom the consenting distributors dealt daily a speedy, inexpensive means to compel the defendants to comply with the provisions of the decree. Many of the exhibitors of the country are united in large trade associations. Though not parties to the action in which the decree was entered, these associations were kept informed of the progress of the negotiations leading to that decree and made known their feelings concerning the various proposals. Generally they were opposed to the decree. Many of the changes in trade practices wrought by the decree were not to their liking. The provisions for arbitration did not appeal to them. Perhaps their experience with the arbitration tribunals which had existed under the old Uniform Licensing Agreement had left them wary of such a procedure. ${ }^{35}$ Whatever the reasons for their reluctance to endorse the Tribunal at the time the consent decree was entered, experience with it and the turmoil created by the abolition of arbitration as a result of the Paramount case have made the exhibitors at present the firmest boosters for industry-wide arbitration.

The Theatre Owners of America, one of the two largest independent exhibitor associations, adopted a resolution, at its convention in Houston, Texas, in October, I950, authorizing its president to invite the presidents of the several producing and distributing companies to attend a meeting at an early date for the purpose of discussing the formulation of an industry arbitration system. ${ }^{36}$ In January 195I, a nationwide poll of exhibitors showed 89.x per cent of those polled to be in favor of arbitration to dispose of industry disputes. ${ }^{37}$ Chief among the reasons given was the difficulty of applying the terms of the new decrees in the Paramount case to specific situations. The exhibitors felt that with an arbitration panel easily accessible there would be less doubt about their rights and thus more certainty in their business plans. ${ }^{32}$ Similarly in June, I95I the national convention of Allied States Associa-

${ }^{33}$ Warburg, Second and Third Quarterly Reports of the Motion Picture Arbitration Tribunals, 5 ARB. J., 286, 289 (194I).

${ }^{34}$ Although the American Arbitration Association's present regulations base the fee upon the amount in dispute (Commercial Arbitration Rules, I47, American Arbitration Association) it is possible that an arrangement could be worked out to cover situations where such a rule might prove inequitable.

${ }^{35}$ Myers, Arbitration and the Independent Exhibitors, 5 ARB. J. 25 (194r). (I95I).

${ }^{36}$ Levy, The Need for a System of Arbitration in the Motion Picture Industry, 5 ARB. J. (N.S.) 262

\$7 Motion Picture Herald, Jan. 27, I95I, p. r2.

${ }^{37 a}$ In a poll of members of "The Herald Institute of Industry Opinion"-a group composed of representatives of exhibition, distribution, and production-94 per cent favored an industry-wide system of arbitration. Communication from the Motion Picture Herald, Jan. II, 1952. 
tion, the other large independent exhibitor group, adopted a resolution calling for an all embracing system of arbitration for the movie industry. ${ }^{38}$ Though there still remains considerable difference between exhibitors and distributors as to what should be arbitrated, there seems complete accord on the merits of arbitration as a method of enforcing an antitrust decree. ${ }^{39}$

\section{IV}

\section{Application to Other INDUSTRIes}

The use of an arbitral system to aid in enforcing antitrust decrees is not advocated for every decree. Regardless of the similarity of the legal principles they may bring into play, it would be difficult to find any two antitrust suits which would present identical industrial and competitive problems. Decision as to whether arbitration can be of value in any particular case must necessarily be left to the sound discretion of the court in which a decree is entered. The same court should prescribe the scope and method of operation of any arbitration procedure it adopts.

Lately a number of antitrust decrees have been entered which require patent owners to license their patents or some of them for a reasonable royalty, ${ }^{40}$ although the debates and reports of Congress indicate the difficulty of determining what is a reasonable royalty in a given situation. ${ }^{41}$ Some decrees set out the criteria of reasonableness to be used. ${ }^{42}$ Others provide that if the applicant for a license considers the requested royalty to be unreasonable he may apply to the court to fix it. ${ }^{43}$ Still others provide merely that the royalty be reasonable, without specifying the criteria or providing for access to the court. ${ }^{44}$ It would appear that arbitration is particularly suited to this type of decree. This is especially true of those decrees which do not accord the complaining prospective licensee a right to apply to the court and leave him with no practical remedy but to beseech the Department of Justice to cite the defendant for contempt. In addition there may well be decided practical advantages in having arbitrators who are experts in the field in question. Certainly experts in the field should be as efficient as any court in deciding whether a particular royalty is reasonable or not.

${ }^{38}$ Motion Picture Herald, Nov. Io, I95I, p. I2.

${ }^{30}$ Motion Picture Herald, Nov. I0, I95I, p. 12; Wright, What Can the Motion Picture Industry Arbitrate, 6 ARs. J. No. 2 (1950).

${ }^{40}$ United States v. Hartford-Empire Co., 65 F. Supp. 27 I (N. D. Ohio I946); United States v. Libbey-Owens-Ford Glass Co., CCH Trade Reg. Serv. 157,489; United States v. American Air Filter Co., CCH Trade Reg. Serv. I57,456.

${ }^{41}$ Hearings before Committee on Patents on H. R. 23,417, Part 12, 62nd Cong. 2d Sess. I0-1I (I912); H. R. Rep. No. ri6r, Part II, 62nd Cong., zd Sess. 8 (I9I2); Report of THE SUb-ComaitTee of the American Bar Association Appointed to Consider the Krug Bill, S. 383, 74th Cong., Ist Sess. 8 (1935).

${ }^{2}$ United States v. Hartford-Empire Co., 65 F. Supp. 27 r (N.D. Ohio r946).

${ }^{43}$ United States v. Diamond Match Co., $\mathrm{CCH}$ TrADE Reg. SERv. $\$ 57,456$; United States v. General Electric Co., CCH TRAde Reg. Serv. \$157,448.

"United States Alien Property Custodian v. Bendix Aviation Corp., CCH Trade Reg. Serv. I57,444; Crosby Stcam Gauge \& Valve Co. v. Manning, Maxwell \& Moore, Inc., CCH Trade Reg. Serv. I57,336. 


\section{Concluston}

Arbitration will not eliminate all the defects that may be discovered in the enforcement of antitrust decrees. Yet it has a place and, as demonstrated by its operation in the motion picture industry, it has great potentialities and value. ${ }^{45}$ Antitrust cases with their numerous practical business problems, problems that often are highly technical, present difficulties enough to the courts. As the number of decrees in antitrust cases increases there will arise greater need for some method of enforcement which will relieve already overburdened courts. A vast reservoir of business talent exists which the courts can tap through the medium of arbitral systems to help enforce their decrees. It may be that experience in other industries will not prove as satisfactory as that in the motion picture industry. On the other hand it may be that it will. Today we can only theorize. The empirical test must be made before definite conclusions are drawn. Arbitration is worth trying.

\section{ADDENDUM}

In Besser Manufacturing Company v. United States, 20 U. S. L. WEEK 4348 (U. S. Sup. Ct., May 26, x952), which was a direct appeal from a judgment of the District Court for the Eastern District of Michigan, the District Court had found that the Government's charges that the appellants and others had combined and conspired to constrain and monopolize commerce in concrete block-making machinery and had monopolized and attempted to monopolize such industry were clearly proved. The Supreme Court held that the conclusions of the District Court were overwhelmingly supported by the evidence.

Appellants contended that provisions of the judgment requiring them to issue patent licenses on a fair royalty basis and to grant to existing licensees an option on terms "mutually satisfactory to the parties concerned," (I) to terminate their leases, (2) to continue their leases, or (3) to purchase the leased machines were "punitive, confiscatory and inappropriate."

The appellants particularly disputed the method adopted by the District Court for fixing reasonable royalty rates. This method consisted of a direction to the appellants and the Government each to select two persons to serve as arbitrators to establish the royalty rates and the form and contents of the royalty contracts, which four persons, in the event of a stalemate, would choose a fifth arbitrator and, if they could not agree on such fifth arbitrator, the trial judge would either act as such fifth arbitrator or appoint some other person to do so. It appears that

\footnotetext{
${ }^{45}$ Hamilton, A Judicial Process for Industry, 5 ARB. J. 50, 58 (I941) makes this interesting observation concerning the arbitration provisions of the motion picture consent decree: "A realization that industrial order lies down another road [i.e., 'other' than formal litigation] is the dominant mark of the result in the motion-picture case. It takes the consent decree, strips from it the character of an elongated injunction, converts it into an instrument of industrial government. Instead of imposing a series of prohibitions upon the industry, it contrives a procedure for bringing its affairs into order. . . . For the circumlocution of litigation, it substitutes the simple, direct, administrative attack of the process of arbitration."
} 
after some delay the four arbitrators were chosen but thereupon an impasse developed and the district judge himself acted as the fifth arbitrator and voted for the rates proposed by the Government-appointed arbitrators. In disposing of the appellants' contentions the Supreme Court (pp. 4349-4350) said:

Appellants' argument fails on two counts. First, it necessarily attacks the sufficiency of the evidentiary material considered in arriving at the royalties finally established. We do not pass on matters of that character in the absence of glaring error not shown here. Secondly, appellants appear to have misunderstood the true nature of what was done, for it was always within the power of the trial judge to establish the royalty rates, and, in voting as he did, he did just that. They contend that the judge should either have held a full hearing himself or referred the royalty matters to a master for such a hearing. We do not, however, think that in reducing the terms of a decree to concrete measures such procedures are mandatory. It is true that the procedure adopted below is an innovation in certain aspects, but novelty is not synonymous with error.

In framing relief in antitrust cases, a range of discretion rests with the trial judge. United States v. National Lead Co., supra, at 338; International Salt Co. v. United States, supra, at 400-401, 405; United States v. Crescent Amusement Co., 323 U. S. 173, 185. We can see no abuse of discretion here. Compulsory licensing and sale of patented devices are recognized remedies. They would seem particularly appropriate where, as here, a penchant for abuses of patent rights is demonstrated. With respect to the procedure for establishing royalty rates, the court below was likewise acting within the discretion vested in it. "[The District Court] should provide for its determination of a reasonable royalty either in each instance of failure to agree or by an approved form or by any other plan in its discretion." United States v. United States Gypsum Co., supra, at 94. (Italics added.) The procedure here was entirely reasonable and fair. A competent committee considered relevant evidence and the judge, on the basis of the evidence adduced before the committee, resolved the deadlock into which the negotiations had fallen.

This decision definitely leans in the direction recommended in this article. It is interesting to note that the Supreme Court, proceeding from the basic principle that a district court in fashioning remedies has wide discretion, concludes that a method adopted by a trial court is not subject to attack provided it leads to a reasonable and fair result. 